\title{
Sosyal Medyanın Tüketicilerin Satın Alma Niyeti Üzerindeki Etkisi
}

\author{
Vesile ÖZÇİ̈Çİ \\ Aksaray Üniversitesi İktisadi ve İdari Bilimler Fakültesi İşletme Bölümü, Aksaray \\ vesileozcifci@aksaray.edu.tr \\ ORCID ID: https://orcid.org/0000-0002-8011-9137
}

\begin{tabular}{lr} 
Araştırma Makalesi & DOI: 10.31592/aeusbed.634148 \\
\hline Geliş Tarihi: 17.10.2019 & Revize Tarihi: 24.02.2020 \\
Atıf Bilgisi & \\
Özçifçi, V. (2020). Sosyal medyanın tüketicilerin satın alma niyeti üzerindeki etkisi. Ahi Evran Üniversitesi \\
$\begin{array}{l}\text { Sosyal Bilimler Enstitüsü Dergisi, 6(1), 206-223. }\end{array}$
\end{tabular}

ÖZ

Sosyal medya, bireylere en uygun ürün ve hizmetler ile ilgili bilgi alışverişinde bulunacağı bir ortam sunarken, işletmelere için de yeni iletişim ve pazarlama kanalları yaratmıştır. Bu araştırma, tüketicilerin sosyal medya aracılığıyla bilgi edinmelerini ve satın almalarını etkileyen faktörlerin neler olduğunu, ayrıca, sosyal medyanın tüketicilerin satın alma niyetine etkisini incelemek amacıyla yürütülmüştür. Verilerin toplanması için oluşturulan bir anketle 592 katılımcıdan veri toplanmıştır. Anket, sosyal medyayı kullanan kişilere hem basılı hem sanal ortamdan ulaştırılmıştır. Toplanan verilerin analizinde Faktör Analizi, Çoklu Standart Regresyon kullanılmıştır. Bulgular, sosyal medyanın özelliklerinin tüketicilerin sosyal medyadan algılanan risk, algılanan değer ve güven faktörlerine göre farklılık gösterdiğini ortaya koymuştur. Algılanan riske en fazla etki sosyal medyanın karşılıklı iletişim değişkeni olmakla beraber, algılanan değer ve güven üzerinde en fazla etkiyi katılım değişkeni yapmaktadır. Algılanan risk üzerinde topluluk, algılanan değer üzerinde karşılıklı iletişim ve bağlantılı olma, güven üzerinde ise açıklık değişkeninin etkisi olmadığı belirlenmiştir. Ayrıca, tüketicilerin sosyal medyadan algılanan risk, algılanan değer ve güvenin satın alma niyetini etkilediği sonucuna ulaşılmıştır. Satın alma niyeti üzerinde en fazla etkisi olan değişkenin algılanan değer olduğu tespit edilmiştir.

Anahtar Kelimeler: Sosyal medya özellikleri, algılanan risk, algılanan değer, güven, satın alma niyeti.

\section{The Impact of Social Media on Consumers' Purchase Intention}

\begin{abstract}
Social media provides individuals with an environment in which they can exchange information about the most appropriate products and services, while creating new communication and marketing channels for businesses. This study has been carried out in order to ascertain the factors that influence the way consumers acquire information and make purchases through social media, and also to examine the effect of social media on consumers' intention to purchase. Data have been amassed from 592 participants by means of a questionnaire arranged for this purpose. The questionnaire was transferred both as a printed copy and through virtual environment to the people who use social media. Factor Analysis and Multiple Standard Regression have been utilized in the analysis of the gathered data. The findings revealed that the characteristics of social media differ according to the consumers' risk perception, value perception, and trust from social media factors. While the conversation variable of social media has come up with the highest impact on perceived risk, perceived value and trust has been primarily influenced by the participation variable. Additionally, it has been determined that community variable possesses no effect on perceived risk, conversation and connectedness variables have no effect on perceived value, and finally, openness variable has no impact on trust. It has also been found out that consumers' perceived risk, perceived value and trust from social media affect their purchase intention. Finally, the findings indicated that the variable that has the greatest effect on purchase intention is perceived value.
\end{abstract}

Key words: Social media characteristics, perceived risk, perceived value, trust, purchase intention.

\section{Giriş}

İnternet kullanımının ve erişiminin artması, bilgilere, ürün ve hizmetlere ulaşım şekillerini değiştirmiştir. Bununla birlikte, İnternet üzerinden ticari faaliyetlerin yürütülmesi için çevrimiçi siteler oluşturulması da pazarda yaşanan önemli değişimlerden biri olmuştur. Bu değişimler tüketicileri çevrimiçi ürün inceleme ve satın almaya yönlendirmiştir. Bu gelişim sürecinde işletmeler, sosyal medya kampanyaları, e-postalar, forumlar ve e-ticaret web siteleri kullanarak hedef kitlelerine yaklaşımlarını değiştirmeye başlamıştır. Sosyal medya platformları bireylere en uygun ürün ve hizmetler ile ilgili bilgi alışverişinde bulunacağı bir ortam sunarken, işletmelere de yeni iletişim ve 
pazarlama kanalları yaratmışıı. Böylece sosyal medya, ürün ve hizmetlerin pazarlanmasında ve tanıtılmasında en popüler iletişim kanallarından biri olmuştur.

We Are Social ve Hootsuit tarafından yayınlanan "Digital in 2019 in Turkey" raporuna göre, ülkemizde internette her gün harcanan ortalama 7 saatin yaklaşı 3 saati sosyal medya kanallarında geçtiği (https://dijilopedi.com) göz önüne alındığında, tüketicilerin sosyal medya platformlardaki davranış verilerinin analizi e-ticaret sektörü için önem taşımaktadır. Sosyal medya, etkin kullanan tüketiciler için firsatlar ve kolaylıklar sunarak satın alımları kolaylaştırmaktadır. Dolayısıyla işletmeler, sosyal medyayı kullanan tüketicilerin ne istediklerini ne düşündüklerini, tüketiciyi etkileyen kişi ve grupların satın alma kararlarını nasıl etkilediğini tespit etmek durumundadır (Chaturvedi, Gupta ve Hada, 2016; Permatasari ve Kuswadi, 2018).

$\mathrm{Bu}$ araştırma, tüketicilerin sosyal medya aracılığıyla bilgi edinmeleri ve satın almalarını etkileyen faktörlerin neler olduğu, ayrıca sosyal medyanın tüketicilerin satın alma niyetine etkisini incelemek amacıyla yürütülmüştür. Bununla birlikte, tüketicileri sosyal ağlarda çevrimiçi satın almalarında etkili olan algılanan risk, algılanan değer ve güven faktörlerinin satın alma niyeti üzerindeki etkisi belirlenmiştir.

\section{Sosyal Medya ve Özellikleri}

Kullanıcıların birbirleriyle, kişisel görüş, bilgi, fikir, tecrübe ya da ilgi alanlarını paylaşarak etkileşimlerine olanak sağlayan her türlü web sitesi sosyal medya olarak kabul edilebilir ve sınıflandırılabilir (Özçifçi, 2019). Sürekli güncellenebilmesi, çoklu kullanıma açık olması, sanal paylaşıma olanak tanıması gibi birçok açıdan sosyal medya en ideal ortamlardan biridir. İnsanlar sosyal medyada düşüncelerini yazmakta, tartışabilmekte ve yeni fikirler ortaya koyabilmektedir. Ayrıca, insanlar, sosyal medya aracılığıyla kişisel bilgilerin yanı sıra fotoğraf, video, paylaşabilmekte, iş arayabilmekte ve hatta bulabilmektedir. Sosyal medya ortamları kişilere gerçek dünyayı sanal ortamda yaşayabilme firsatı sunmaktadır (Vural ve Bat, 2010).

Sosyal medya, ilişki kurma, güven oluşturma, diğer insanlara ulaşma ve onlarla bağlantı kurmada etkili bir iletişim süreci olmakla birlikte, bilişim teknolojilerinin kullanılması ile ilgili olup bir takım temel özelliklere sahiptir. Bu özellikler aşağıdaki gibi sıralanabilir (Mayfield, 2008):

Katılım: Sosyal medya ilgili olan tüm kullanıcıları cesaretlendirir ve geri bildirim sağlar.

Açıklık: Sosyal medya servislerinin çoğu geri bildirime ve katılımlara açıktır. Bununla birlikte oylama, yorum ve bilgi paylaşımını teşvik eder. Sosyal medyada içeriğe erişim ve içerik kullanımında nadiren engel bulunmaktadır.

Karşılıklı iletişim: Geleneksel medya, içerik aktarımını veya kullanıcılara bilgi ulaşımını bir kaynaktan sağlamaktadır. Ancak sosyal medya da iki yönlü bir iletişim ve etkileşim söz konusudur.

Topluluk: Sosyal medya, çeşitli toplulukların oluşturulmasını ve bu toplulukların etkili bir şekilde iletişim kurmasını sağlar. Böylece oluşturulan topluluklar ortak ilgi alanlarını paylaşabilmektedir.

Bağlantıll olma: Sosyal medya sitelerinin birçoğu, başka sitelerle ve net ortamlarıyla bağlantılıya olanak sağlamakta veya mevcut bağlantıları geliştirmektedir. Ayrıca, diğer sitelere, kaynaklara ve kişilere link vererek iletişim yoğunluğunu artırmaktadır (Vatandaş, 2017).

Sosyal medya, etkin kullanan tüketicilere katma değer (kişisel pazarlama, ürün bilgisi arama, iş arama vb.) sağlayarak hayatlarını kolaylaştırmaktadır. Sosyal medyayı etkin kullanmak sadece bireyler için değil, aynı zamanda pazarda rekabet etmek isteyen işletmeler için de önemlidir. İşletmeler sosyal medyayı kullanarak müşterilerle doğrudan iletişim kurabilmekte, tüketiciler de 
ürünler ile ilgili görüşlerini bildirebilmektedir. Pazarlama stratejisinin bir parçası olarak sosyal medyanın özelliklerini anlamadan etkin bir şekilde kullanmayan işletmeler başarısızlığa mahkûm olacaktır (Chen, 2014). Bu nedenle, sosyal medya platformlarındaki bağlantılar, sosyal medyanın bilgileri yaymada hızlı ve etkileşimli yapısı, işletmeleri sosyal medya platformlarını kullanma ve uygulamada yeni pazarlama stratejileri geliştirmek zorunda bırakmıştır.

\section{Algılanan Risk}

Algilanan risk kavramı ilk olarak Bauer (1967) tarafindan bilgi arama ve marka sadakati gibi kavramları açıklamak için psikolojik, öznel bir yapı olarak ortaya konulmuştur (Hassan, Kunz, Pearson ve Mohamed, 2006). Algılanan risk, tüketicilerin satın aldıkları kararların sonuçlarını öngöremediklerinde karşılaştıkları belirsizlik olarak tanımlanmaktadır. Algılanan fayda, kullanıcıların ürünlerden veya hizmetlerden elde ettikleri faydalarla ilgili iken; risk, ürün veya hizmetleri elde etmek için ödenen maliyetleri ifade etmektedir (Gan ve Wang, 2017).

Algılanan risk, temel tüketici davranışı kavramı olarak kabul edilmekte ve müşterilerin risk algılarını ve bunları azaltma yöntemlerini açıklamak için sıklıkla kullanılmaktadır. İnsanlar hata yapmaktan kaçındıkları için algılanan risk, tüketici davranışlarını önemli ölçüde yönlendirmektedir. Bu bağlamda algılanan risk, alıcı davranışındaki tek açıklayıcı faktör olmasa da satın alma kararının ayrılmaz bir parçası olarak düşünülmektedir (Maziriri ve Chuchu, 2017). Algılanan risk, satın alma kararı sürecinde bir tüketici tarafindan algılanan riskin niteliğini ve miktarını ifade etmektedir (Khan ve Chavan, 2015).

İnternet'ten alışverişte algılanan risk, çevrimiçi satın alma düşüncesindeki müşteri tarafından öznel olarak belirlenmiş kayıp beklentisidir. Çevrimiçi alışverişte, tüketiciler her bir risk türü için birden fazla endişe belirtmektedir (Kalburan ve Haşıloğlu, 2015). İnternetten alışverişle ilgili olarak en sık belirtilen risk; finansal risk, ürün riski, uygunluk ve teslim edilmeme riskidir. Algılanan risk ne kadar düşük olursa, çevrimiçi alışveriş eğilimi de o kadar yüksek olmaktadır (Javadi, Dolatabadi, Nourbakhsh, Poursaeedi ve Asadollahi, 2012). Bununla birlikte, algılanan risk, tüketicilerin çevrimiçi alışveriş davranışlarına, çevrimiçi alışveriş alışkınlığına ve deneyimlerine bağlı olarak farklı etkilere sahip olabilmektedir (Forsythe ve Shi, 2003).

Tüketici açısından algılanan risklerin incelenmesinde önemli üç nedenin olduğu ileri sürülmektedir. İlk olarak, algılanan risk teorisi sezgisel çekiciliğe sahiptir ve dünyayı müşterilerin gözünden görmelerini kolaylaştırmada pazarlamacılar için önemli bir rol oynamaktadır. İkincisi, çok çeşitli pazarlama uygulamalarında kullanılmaktadır. Üçüncüsü ise, tüketicilerin satın alma kararlarında hatalardan kaçınmak, faydayı maksimize etmekten daha etkili olmaktadır. Bu yüzden, tüketicilerin davranışlarını açıklamada algılanan risk önemli rol oynamaktadır (Hassan vd., 2006).

\section{Algılanan Değer}

"Değer" kavramı pazarlamada kilit bir unsurdur (Demirgüneş, 2015). Değer, bir ürünün faydaları ile onu elde etme maliyetleri arasındaki farkı ifade etmektedir. Tüketiciler gerçek anlamda ürünün değeri ile maliyetini tam ve somut olarak tanımlayamamaktadır. Bu yüzden tüketicinin ifade ettiği değer, algıladığı değer anlamına gelmektedir. Tüketiciler günümüzde ihtiyaçlarını karşılayabilecek pek çok ürün ya da marka ile karşılaşmaktadır. Bu kadar çeşit arasından satın alma kararını vermeleri belli kriterlere, değerlendirmelere dayanmaktadır. Günümüzde tüketici ürünlerin kendisine sunduğu değerleri algılayış biçimine ve ürünün kendisine ne ifade ettiğine göre satın alma kararını vermektedir (Uzunoğlu, 2007). Bu bağlamda tüketici açısından algılanan değer, tüketicilerin kazanabileceği faydalar ile ürün veya hizmet için ödeyecekleri maliyetler arasındaki fark olarak açiklanabilir (Chen, 2014).

Zeithaml (1988, s.14) algılanan değeri, "tüketicilerin, bir ürünün (veya hizmetin) kullanımında ne alındığına ve ne verildiğine ilişkin algılarına bağlı olarak değerlendirmesi” şeklinde tanımlamaktadır. Bununla birlikte, tüketicilerin değer algılamaları kalite ve fiyata ilişkin 
algılamalarından etkilenmekte ve fiyatın adil olup olmadığına ilişkin algılamalarıyla ortaya çıkmaktadır (Türkmendă̆ ve Köroğlu, 2018). Diğer yandan, algılanan değer, ek yararları, bir bedel ödetmeden müşterilere sunmaktır. Bu noktada, beklenen ve algılanan durum ön plana çıkmakta ve algılanan değer, müşterinin bir üründen ne elde ettiği ile ürünü elde ederken ne gibi fedakarlıklarda bulunduğu arasındaki değiş tokuşu kapsamaktadır (Eskiler ve Altunışık, 2014). Değer, fayda ve fedakârlık çerçevesinde ele alındığında, müşterinin algıladığı değer, müşterinin elde ettiği fayda algısı ile yapılan fedakârlık arasındaki fark olarak tanımlanmaktadır (Tektaş ve Kavak, 2010).

Literatür incelendiğinde algılanan değer ile ilgili araştırmalar iki temel yaklaşım çerçevesinde şekillenmektedir. $\mathrm{Bu}$ yaklaşımlardan ilki, algılanan değerin tek boyutlu bir yapıya sahip olduğu üzerine odaklanmakta ve algılanan değerin tek bir genel ifade ile ölçülebileceğini vurgulamaktadır. Diğer yaklaşım, algılanan değerin birbiri ile bağlantılı özelliklerinden oluşan çok boyutlu bir kavram olduğu yönündedir (Cocosila ve Igonor, 2012; Eskiler ve Altunışık, 2014). Tek boyutlu yaklaşım, fiyat algısına veya algılanan kalite ile fedakârlık arasındaki dengeye dayanmaktadır. Bu yaklaşım algılanan değerin karmaşık ve çok yönlü doğasını ayırt edemediği için eleştirilmiş̧ir. Bu yüzden bu karmaşık kavramın bütünsel bir görünümünü sağlamak için çok boyutlu müşteri algılanan değer modelleri ortaya konulmuştur (Chuah, Marimuthu ve Ramayah, 2014). Karmaşıklığı ve çok taraflı yaklaşımı nedeniyle algılanan değer, sosyal medya uygulamalarının araştırmak için bir mercek görevini görmektedir (Cocosila ve Igonor, 2012).

"Yeni pazarlama çılgınlı̆̆ı" ve "90'larda satışın yolu" olarak adlandırılan algılanan değer, üretici ve perakendeciler için stratejik bir zorunluluk olarak belirtilmekte, bu zorunluluğun yirmi birinci yüzyılda da aynı önemle devam edeceği vurgulanmaktadır (Alarçin, 2015).

\section{Güven}

Güven, tüketicilerin çevrimiçi alışveriş davranışlarını etkileyen önemli değişkenlerden biridir. Algılanan risklere rağmen çevrimiçi yapılan işlemlerin yoğunluğu, yalnızca sunulan tahmini faydalara değil, aynı zamanda çevrimiçi işlemlerde kullanılan teknolojiye ve işlemlerin diğer tarafları olan kuruluşlara olan güvene de bağlıdır (Beldad, Jong ve Steehouder, 2010). Sosyal medya ortamları ve bu ortamdaki kişilere olan güven düzeyi, kişilerin güvenle iletişim kurmalarına ve paylaşımda bulunmalarına olumlu katkı sağlamaktadır. Sosyal medya ortamlarına olan güven eksikliği kullanıcıları gizlilik konusunda endişelendirip paylaşıma yönelik tutumları üzerinde olumsuz bir etki yaratırken, bir sosyal medya ortamına olan yüksek seviyedeki güven, kullanıcıların bilgi paylaşmalarına ve paylaşıma yönelik tutumlarını olumlu yönde geliştirmektedir (Baş, 2018). Tüketicilerin sosyal medyada belirli platform kullanıp kullanmamaları önceki deneyimlere, özellikle de ona ne kadar güven duyduklarına bağlı olmaktadır (Chen, 2014).

Günümüzde tüketiciler, sosyal medya ile daha fazla bağlantılı oldukları için, ürünlere yönelik algıları ve güvenleri, sosyal medya ortamındaki yorum, görüş ve topluluklardan oldukça etkilenmektedir (Aren, Güzel, Kabaday1 ve Alpkan, 2013; Chaturvedi vd., 2016; Ling, Chai ve Piew, 2010). Bununla birlikte; güven, bir çevrimiçi mağazanın hem potansiyel hem de sürekli müşterileri için satın alma niyetleri üzerindeki algılanan fiyattan daha iyi bir etki yaratarak markalara bağlılık yaratmaktadır (Chaturvedi, vd., 2016).

\section{Satın Alma Niyeti}

Satın alma niyeti, tüketicilerin satın alma işlemini yürütmek için istekli olma olasılığıdır (Chen, 2014). Satın alma niyeti, "tüketicinin belirli bir zaman aralığında belirli bir markadan ya da üründen belirli bir miktarda satın almayı planlaması ve belirli bir ürün veya hizmeti satın almak için tüketicinin niyeti” olarak da tanımlanabilir (Çetin ve Kumkale, 2016). İnternet'te satın alma niyeti ise, tüketicinin çevrimiçi işlemlere istekli ve dahil olma niyetinde olması durumudur. $\mathrm{Bu}$ çevrimiçi işlemler bilgi edinme, bilgi transferi ve ürünü satın alma faaliyeti olarak kabul edilmektedir (Akel, 2015). 
Satın alma niyeti tüketicinin öngörülebilir davranışını göstermekte, yani tüketicilerin alışveriş yaptıklarında bir dahaki sefere hangi ürünleri veya markaları satın alacağını tahmin etmek için kullanabilmektedir (Fandos ve Flavian, 2006). Sosyal medyanın artan kullanımı ise, müşterilere fikir alışverişinde bulunabilmeleri için firsat vermiştir. İnternet ortamında bilginin kalitesi, müşterinin, bir firmanın ürün ve hizmetlerini satın alma kararını etkilemekte, bilgiyi kullanan müşterilerin web sitesini ailesine ve arkadaşlarına tavsiye etme isteği oldukça yüksek olmaktadır (Esen, 2012).

\section{Yöntem}

Sosyal medyayı farklı açılardan ele alan çalışmalar olmakla birlikte, özelliklerini sistematik olarak tanımlayan çok az teorik çalışma mevcuttur. Çalışmanın temel amacı sosyal medyanın günlük hayattaki kritik önemini, tüketicilerin sosyal medya aracilığıla bilgi edinmelerine ve satın almalarına etki eden faktörleri ve sosyal medyanın tüketicilerin satın alma niyetine etkisini tespit etmektir. $\mathrm{Bu}$ temel amacı karşılayabilmek için geliştirilen hipotezlere aşağıda yer yer verilmiştir:

Araştırmada test edilecek hipotezler:

$\mathrm{H}_{1}$ : Sosyal medyanın $\left(\mathrm{H}_{1 \mathrm{a}}\right)$ katılım, $\left(\mathrm{H}_{1 \mathrm{~b}}\right)$ açıklık, $\left(\mathrm{H}_{1 \mathrm{c}}\right)$ karşıllıklı iletişim, $\left(\mathrm{H}_{1 \mathrm{~d}}\right)$ topluluk ve $\left(\mathrm{H}_{1 \mathrm{e}}\right)$ bağlantılı olma özelliği tüketici tarafindan algılanan riski etkiler.

$\mathrm{H}_{2}$ : Sosyal medyanın $\left(\mathrm{H}_{2 \mathrm{a}}\right)$ katılım, $\left(\mathrm{H}_{2 \mathrm{~b}}\right)$ açıklık, $\left(\mathrm{H}_{2 \mathrm{c}}\right)$ karşıllıklı iletişim, $\left(\mathrm{H}_{2 \mathrm{~d}}\right)$ topluluk ve $\left(\mathrm{H}_{2 \mathrm{e}}\right)$ bağlantılı olma özelliği tüketici tarafindan algılanan değeri etkiler.

$\mathrm{H}_{3}$ : Sosyal medyanın $\left(\mathrm{H}_{3 \mathrm{a}}\right)$ katılım, $\left(\mathrm{H}_{3 \mathrm{~b}}\right)$ açıklık, $\left(\mathrm{H}_{3 \mathrm{c}}\right)$ karşılıklı iletişim, $\left(\mathrm{H}_{3 \mathrm{~d}}\right)$ topluluk ve $\left(\mathrm{H}_{3 \mathrm{e}}\right)$ bağlantılı olma özelliği tüketicinin sosyal medyaya duyduğu güveni etkiler.

$\mathrm{H}_{4}$ : Tüketicinin sosyal medyadan algıladığı risk tüketicinin satın alma niyetini etkiler.

$\mathrm{H}_{5}$ : Tüketicinin sosyal medyadan algıladığı değer tüketicinin satın alma niyetini etkiler.

$\mathrm{H}_{6}$ : Tüketicinin sosyal medyaya duyduğu güven tüketicinin satın alma niyetini etkiler.

Yukarıda yer verilen hipotezler araştırma modeli olarak Şekil 1'de sunulmuştur.

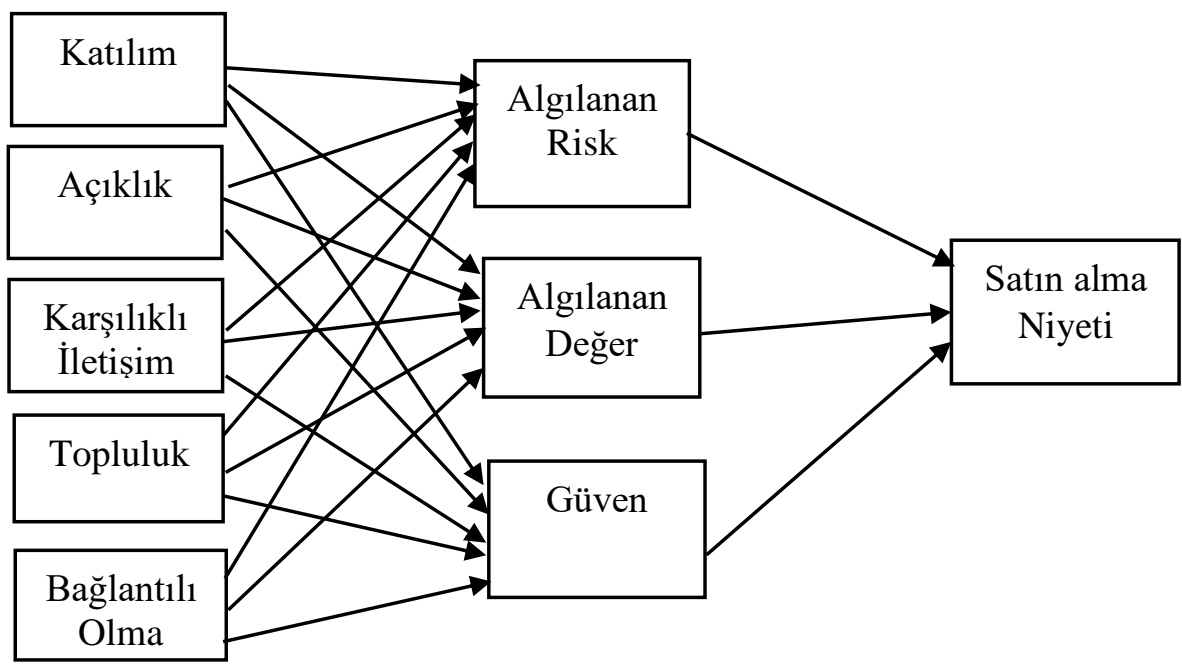

Şekil 1. Araştırma Modeli 


\section{Evren ve Örneklem}

Araştırmanın hedef kitlesi sosyal medyayı kullanan 18 yaş ve üstü kişilerdir. Ulaşılmak istenen kitlenin büyük olması ve örnekleme çerçevesinin olmaması nedeniyle kolayda örnekleme yöntemi seçilmiştir. 620 katılımcıdan veri toplanmış bunlardan kullanılabilir 592 anket analizlerde değerlendirilmiştir. Katılımcıların \%44’ü İç Anadolu Bölgesi \%38'i Akdeniz Bölgesi olmak üzere $\% 18$ 'i diğer bölgelere yayılmaktadır.

\section{Veri Toplama Aracı}

Yürütülen çalışmada veri toplamada anket yönteminden yararlanılmıştır. Anket, katılımcılara hem internet ortamından hem de basılı olarak Ekim 2018 ile Aralık 2018 tarihleri arasında gönderilmiştir Anket iki kısımdan oluşmaktadır. Birinci kısımda katılımcılara iliş̧in demografik özellikler yer almaktadır. İkinci kısımda sosyal medyanın temel beş özelliğine ilişskin ifadeler, Myfield, 2008; Chen, 2014 sosyal medyadan algilanan risk ile ilgili 6 ifade Hassan, vd., 2006; Algılanan değer ile ilgili 3 ifade; Zeithaml, 1988; Petrick, 2004; Güven ile ilgili 4 ifade Chen, 2014; satın alma niyetine ilişkin 4 ifade Wang ve Chang (2013); McKnight ve Chervany (2002)'nin çalışmalarından yararlanılarak oluşturulmuştur. Katılımcılara belirtilen ifadelere kesinlikle 1=katılmıyorum'dan 5=kesinlikle katılıyorum'a doğru derecelendirilen 5'li Likert tipi ölçek üzerinden cevap vermeleri istenmiştir.

Anket formunun geliştirilmesinde literatür taraması ile birlikte akademisyen, öğrenciler ve sosyal medyayı aktif kullanan kişilerle odak grup çalışması yapılmıştır. Anket formunun değerlendirilmesi amacıyla 25 kişilik bir pilot çalışma ile ankete son hali verilmiştir.

\section{Verilerin Analizi}

Verilerin analizinde SPSS programı kullanılmıştır. Modelde yer alan değişkenlerin boyutlarını belirlemek için faktör analizinden yararlanılmıştır. Sosyal medya özelliklerinin tüketici tarafindan algılanan risk, algılanan değer ve güven üzerindeki, ayrıca tüketici tarafından algılanan risk, algılanan değer ve güvenin satın alma niyeti üzerindeki etkisini belirlemek için Standart Çoklu Regresyon Analizi uygulanmıştır.

\section{Bulgular}

Elde edilen verilerden katılımciların demografik özelliklerine ait bilgiler Tablo 1'de sunulmuştur.

Tablo 1

Katılımcıların Demoğrafik Özellikleri

\begin{tabular}{clrrrlrr}
\hline Özellik & & Sayı & $\%$ & Özellik & & Say1 & \multicolumn{1}{c}{$\%$} \\
\hline \multirow{3}{*}{ Cinsiyet } & Kadın & 362 & 61,1 & & İlkokul & 9 & 1,5 \\
& Erkek & 230 & 38,9 & & Ortaokul & 29 & 4,9 \\
& & & & Öğrenim & Lise & 175 & 29,6 \\
Medeni & Evli & 288 & 48,7 & Durumu & Üniversite & 339 & 57,3 \\
Durum & Bekar & 304 & 51,3 & & Y.Lisans & 33 & 5,6 \\
& & & & & Doktora & 7 & 1,1 \\
& $18-22$ & 142 & 24,0 & & 1500 ve altı & 179 & 30,2 \\
& $23-27$ & 117 & 19,8 & & $1501-2500$ & 94 & 15,9 \\
& $28-32$ & 76 & 12,8 & Aylık gelir & $2501-3500$ & 109 & 18,4 \\
Yaş & $33-37$ & 51 & 8,6 & & $3501-4500$ & 107 & 18,1 \\
& $38-42$ & 63 & 10,6 & & $4501-5500$ & 71 & 12,0 \\
& $43-47$ & 68 & 11,5 & & 5501 ve üstü & 32 & 5,4 \\
& 48 yaş ve üstü & 75 & 12,7 & & & & \\
\hline
\end{tabular}


Katılımcıların sosyal medya kullanımına ilişkin veriler Tablo 2'de verilmiştir.

Tablo 2

Katılımcıların Sosyal Medya Kullanımı

\begin{tabular}{llrrllrr}
\hline & \multicolumn{1}{c}{ Sayı } & \multicolumn{1}{c}{$\%$} & & Sayı & $\%$ \\
\hline Sosyal & Günlük & 286 & 48,3 & Sosyal & 1 saaten az & 136 & 23,0 \\
ağlara & Haftada 2-4 kez & 165 & 27,9 & ağlarda & 2 saat & 153 & 25,8 \\
giriş & Haftada 1 kez & 55 & 9,3 & bağlı & 3 saat & 88 & 14,9 \\
sıklığ & Ayda 2-4 kez & 22 & 3,7 & kalma & 4 saat & 44 & 7,4 \\
& Ayda 1 kez & 64 & 10,8 & süresi & 5 saat ve üstü & 171 & 28,9 \\
\hline
\end{tabular}

Çalışmada faktör analizi ile sosyal medyanın özellikleri, tüketicinin sosyal medyadan algılanan fayda, algılanan değer, güven ve satın alma niyeti ölçeklerinin boyutları belirlenmeye çalışılmıştır. Araştırmada yer alan değişkenlere ilişkin uygulanan faktör analizinde varimaks rotasyonlu temel bileşenler faktör analizi uygulanmıştır. Boyutların tespitinde faktörlerin 1'den büyük özdeğere sahip olmaları ve faktör yüklerinin 0.50'den büyük olmaları koşulu aranmıştır (Hair, Anderson ve Tatham, 1998). Bununla birlikte $\mathrm{KMO}>0,50$ olması faktör analizi yapılan örneklemin yeterli olduğunu göstermektedir (Tabachnick ve Fidell, 2001).

Araştırmada yer alan ölçeklerin güvenirliliklerini test etmek amacıyla Cronbach Alfa katsayısı kullanılmıştır. Kullanılan ölçeklerin alfa değerleri 0,60'ın üzerinde olması ölçeklerin güvenilir olduğunu göstermektedir (Malhotra, 1999).

Sosyal medya özellikleri ölçeği için yürütülen faktör analizi sonuçları Tablo 3’te verilmiştir.

Tablo 3

Sosyal Medya Özellikleri Ölçeğine İlişkin Keşifsel Faktör Analizi Sonuçları

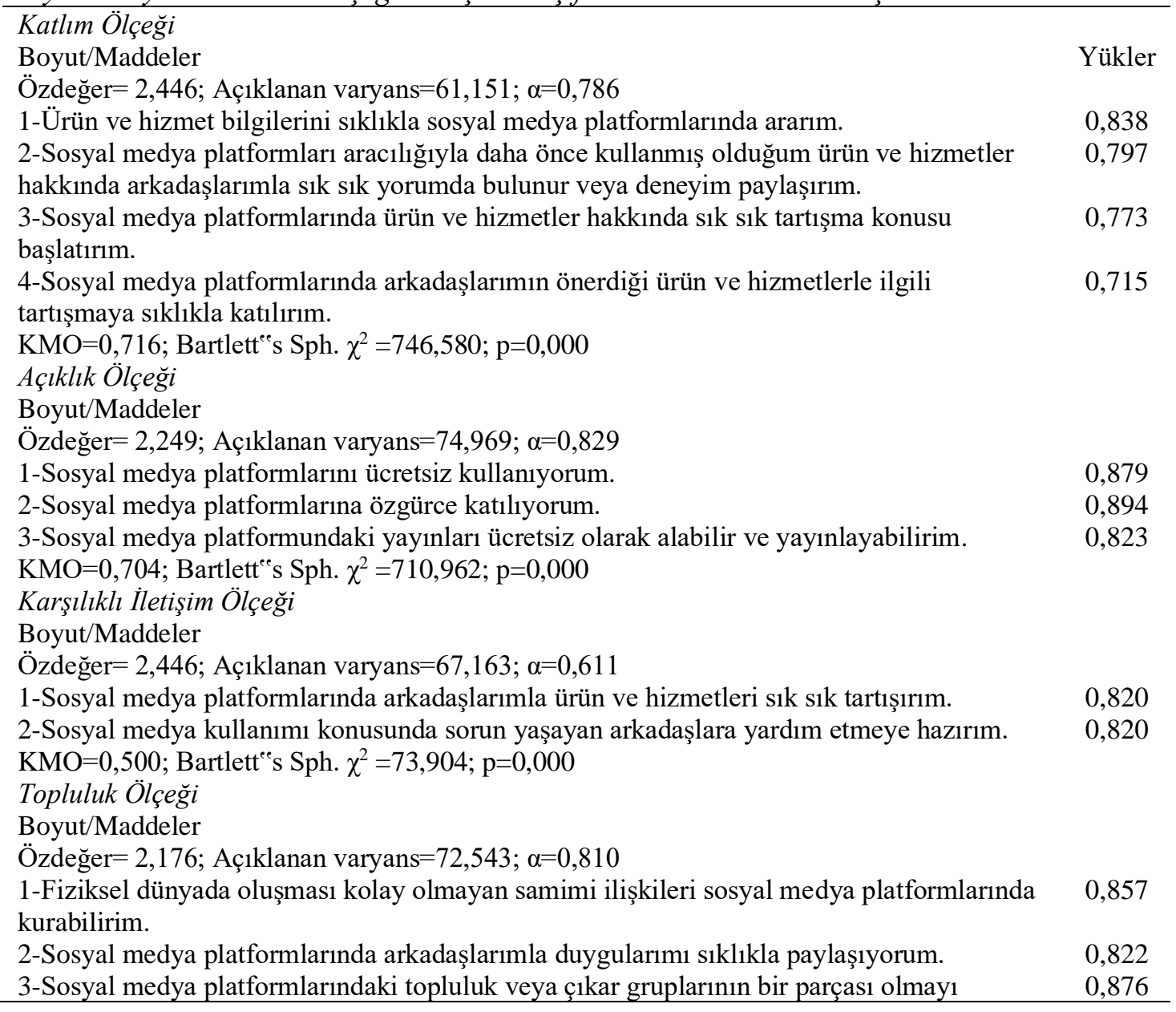


seviyorum.

$\mathrm{KMO}=0,705$; Bartlett ${ }^{\mathrm{ee}} \mathrm{S}$ Sph. $\chi^{2}=601,610 ; \mathrm{p}=0,000$

Bağlantılı Olma Ölçeği

Boyut/Maddeler

Özdeğer=1,913; Açılklanan varyans $=63,762 ; \alpha=0,714$

1-Farklı sosyal medya platformlarında oturum açmak için sıklıkla aynı sosyal medya

kimliğini kullanırım.

2-Çoğu zaman diğer sosyal medya platformlarında içerik paylaşıyorum ve bağlantılar

aracılığıyla bir sosyal medya ağına yüklüyorum.

3-Sosyal medya platformlarındaki bilgileri metin, ses, resim, video vb. şeklinde

düzenleyebilir ve iletebilirim.

$\mathrm{KMO}=0,670$; Bartlett ${ }^{\mathrm{ee}} \mathrm{S}$ Sph. $\chi^{2}=342,969 ; \mathrm{p}=0,000$

Tablo 3'te görüldüğü gibi, sosyal medya özelliklerinden katılım, açıklık, karşılıklı iletişim, topluluk, bağlantılı olma ölçeği özdeğeri 1'den büyük tek boyutta toplanmıştır. Topluluk ölçeğinden bir maddenin faktör yükü 0,50'nin altında olduğu için analizlerden çıkarılmıştır. Katılım ölçeği varyansın toplam \%61,151'ini; açıklık ölçeği \%74,969'unu; karşılıklı iletişim ölçeği \%67,163'ünü; topluluk ölçeği \%72,543’ünü; bağlantılı olma ölçeği \%63,762'sini açıklamaktadır.

Algılanan risk ölçeğine ilişkin yürütülen faktör analizi sonuçları Tablo 4'te verilmiştir.

Tablo 4

Algılanan Risk Ölçeğine İlişkin Keşifsel Faktör Analizi Sonuçları

\section{Boyut/Maddeler}

Özdeğer= 2,618; Açıklanan varyans=65,447; $\alpha=0,819$

1-Sosyal medya platformları üzerinden ürün ve hizmet satın almak için çok fazla zaman

Yükler

harcama olasılığımın yüksek olduğunu düșünüyorum.

2-Sosyal medya platformları ile ürün ve hizmet satın alarak fiziksel ve psikolojik sağlığımı zarara uğratma ihtimalinin düşük olduğunu düşünüyorum. (Bilgisayar ekranına uzun süre maruz kalma, malların bekleyişinin gelmesi, vb.)

3-Sosyal medya platformları ile ürün ve hizmet satın alma konusunda gizliliğimi sızdırma olasılığının düşük olduğunu düşünüyorum.

4-Sosyal medya platformları ile ürün ve hizmet satın almada beni sosyal baskı altına alma olasılığının düşük olduğunu düşünüyorum (davranışlarımı arkadaşlarımın onayı gibi)

$\mathrm{KMO}=0,784$; Bartlett ${ }^{\mathrm{ee}} \mathrm{s}$ Sph. $\chi^{2}=872,510 ; \mathrm{p}=0,000$

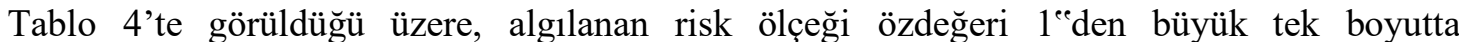
toplanmıştır. Algılanan risk ölçeğinden iki maddenin faktör yükü 0,50'nin altında olduğu için analizlerden çıkarılmıştır. Algılanan risk ölçeği varyansın toplam \%65,447'sini açıladığı belirlenmiștir.

Algılanan değer ölçeğine ilişkin yürütülen faktör analizi sonuçları Tablo 5'te verilmiştir.

Tablo 5

Algılanan Değer Ölçeğine İlişkin Keşifsel Faktör Analizi Sonuçları

\begin{tabular}{lc}
\hline Boyut/Maddeler & Yükler \\
Özdeğer=1,870; Açılanan varyans=62,341; $\alpha=0,697$ & \\
$\begin{array}{l}\text { 1-Sosyal medya platformlarında ürün ve hizmetler hakkında bilgi edindikten sonra, } \\
\text { bunların kalitesini ve işlevini daha iyi biliyorum. }\end{array}$ & 0,767 \\
$\begin{array}{l}\text { 2-Sosyal medya platformlarında kişisel kalite tercihim ve stilime uygun ürün ve hizmetleri } \\
\text { bulabilirim. }\end{array}$ & 0,802 \\
$\begin{array}{l}\text { 3-Sosyal medya ağlarında ürün ve hizmetler hakkında çok fazla zaman ve enerji } \\
\text { harcıyorum. }\end{array}$ & 0,800 \\
\hline $\mathrm{KMO}=0,670 ;$ Bartlett ${ }^{\text {ee }}$ Sph. $\chi^{2}=306,487 ; \mathrm{p}=0,000$ &
\end{tabular}

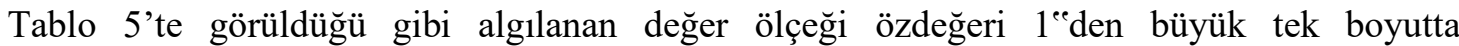
toplanmıştır. Algılanan değer ölçeği varyansın toplam \%62,341'ini açıkladığı belirlenmiştir. 
Güven ölçeğine ilişkin yürütülen faktör analizi sonuçları Tablo 6'da verilmiştir.

Tablo 6

Güven Ölçeğine İlişskin Keşifsel Faktör Analizi Sonuçları

Boyut/Maddeler

Özdeğer $=2,357$; Açıklanan varyans $=78,579 ; \alpha=0,864$

Yükler

Sosyal medyaya dair bilgilerin güvenilir olduğunu düşünüyorum.

Sosyal medyadaki arkadaşların güvenilir olduğunu düşünüyorum.

0,883

Kullandığım sosyal medyanın güvenilir olduğunu düşünüyorum.

$\mathrm{KMO}=0,736$; Bartlette's Sph. $\chi^{2}=835,863 ; \mathrm{p}=0,000$

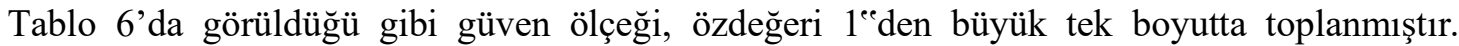
Güven ölçeğinden bir maddenin faktör yükü 0,50'nin altında olduğu için analizlerden çıkarılmıştır. Güven ölçeği varyansın toplam \%78,579'unu açıkladığı tespit edilmiştir.

Satın alma niyeti ölçeğine ilişkin yürütülen faktör analizi sonuçları Tablo 7'de verilmiştir.

Tablo 7

Satın Alma Niyeti Ölçeğine İlişkin Keşifsel Faktör Analizi Sonuçları

\begin{tabular}{lc}
\hline Boyut/Maddeler & Yükler \\
\hline $\begin{array}{l}\text { Özdeğer=2,680; Açıklanan varyans=66,989; } \alpha=0,833 \\
\text { Sosyal medya platformların kullanmak, mal ve hizmet satın almadan önce kararları daha } \\
\text { iyi almamı sağlar. }\end{array}$ & 0,777 \\
$\begin{array}{l}\text { Sosyal medya platformlarını kullanmak, ürün ve hizmet satın alma konusundaki ilgimi } \\
\text { artırıyor. }\end{array}$ & 0,815 \\
$\begin{array}{l}\text { Ürünlerin veya hizmetlerin kullanımının para, zaman ve enerji açısından kişisel } \\
\text { bağllıklardan daha faydalı olduğunu görürsem, bu ürünleri veya hizmetleri satın almayı } \\
\text { düşünürüm. }\end{array}$ & 0,867 \\
$\begin{array}{l}\text { Sosyal medya platformlarında arkadaşlarım tarafından önerilen ürün veya hizmetleri satın } \\
\text { alma olasıllı̆ım çok yüksektir. }\end{array}$ & 0,813 \\
$\mathrm{KMO}=0,777 ;$ Bartlett"s Sph. $\chi^{2}=927,097 ; p=0,000$ & \\
\hline
\end{tabular}

Tablo 7'de satın alma niyeti ölçeği özdeğeri 1“eden büyük 4 madde tek faktörlü bir yapı olarak ortaya çıktığı görülmektedir. Satın alma ölçeği varyansın toplam \%66,989'unu açıkladığı belirlenmiştir.

Sosyal medya özelliklerinin tüketici tarafindan algılanan risk, algılanan değer ve güven üzerindeki, ayrıca tüketici tarafından algılanan risk, algılanan değer ve güvenin satın alma niyeti üzerindeki etkisini belirlemek için Standart Çoklu Regresyon Analizi uygulanmıştır. Analize ilişkin normal dağılım, doğrusallık, sabit varyans, otokorelasyon olmaması ve bağımsız değişkenler arasında çoklu bağlantı olmaması gibi varsayımlar söz konusudur.

Verilerin çarpıklık ve basıklık değerleri \pm 3 arasında yer almaktadır. Dolayısıyla verilerin normal dağılıma uygun olduğu söylenebilir (Erol, 2012). Bununla birlikte bağımsız değişkenler arasında $0,80^{\prime}$ in üzerinde korelasyon olması bağımsız değişkenler arasında çoklu bağlantının olabileceğini göstermektedir. Gözlem değerleri arasında otokorelasyon olup olmadığının test edilmesi için Durbin-Watson Testi (DW) kullanılmaktadır. Genellikle 1,5-2,5 arasında DW değeri kabul edilmektedir. Ayrıca VIF değerlerinin de 10'dan çok daha düşük olması değişkenler arasında çoklu bağlantı sorunu bulunmadığına işaret etmektedir (Küçüksille, 2010).

Sosyal medya özelliklerinin algılanan riske etkisini tespit etmek amaciyla çoklu regresyon analizi uygulanmadan önce değişkenler arasında çoklu bağlantının olup olmadığını tespit etmek için bağımsız değişkenler arasındaki ikili korelasyonlar incelenmiştir. Tablo 8 incelendiğinde bağımsız değişkenler arasında 0,80'nin üzerinde bir korelasyon değeri bulunmamıştır. 
Tablo 8

Değişkenler Arasındaki Korelasyon Değerleri

\begin{tabular}{lccccc}
\hline $\mathrm{N}=592$ & Katılım & Açıklı & $\begin{array}{c}\text { Karşılıklı } \\
\text { Iletişim }\end{array}$ & Topluluk & $\begin{array}{c}\text { Bağlantıllı } \\
\text { Olma }\end{array}$ \\
Katılım & & & & 0,590 & 0,542 \\
Açıklık & 1,000 & 0,423 & 0,679 & 0,579 & 0,617 \\
Karşlıklı İletişim & & 1,000 & 0,442 & 0,533 & 0,477 \\
Topluluk & & 1,000 & 0,533 & 0,622 \\
Bağlantılı olma & & & 1,000 & 1,000 \\
\hline
\end{tabular}

Sosyal medya özelliklerinin algılanan riske etkisini tespit etmek amaciyla yapılan regresyon analizi sonuçları Tablo 9'da gösterilmektedir. Ayrıca yapılan analiz sonucunda DW 1,737; VIF $(1,99$ 2,23 arasında değişen) değerlerinin kabul edilebilir düzeyde olduğu tespit edilmiştir.

Tablo 9

Sosyal Medya Özelliklerinin Algılanan Riske Etkisi: Regresyon Analizi Sonuçları

\begin{tabular}{lccc}
\hline Bağımsız Değişkenler & $\begin{array}{c}\text { Standartlaştırılmış Beta } \\
\text { Katsayıları }\end{array}$ & $\mathrm{t}$ & $\mathrm{p}$ \\
\hline Katılım & 0,270 & 8,820 & 0,000 \\
Açıllık & 0,209 & 6,879 & 0,000 \\
Karşılıklı İletişim & 0,372 & 13,093 & 0,000 \\
Topluluk & 0,027 & 0,850 & 0,396 \\
Bağlantılı olma & 0,175 & 5,865 & 0,000 \\
Bağımlı Değişken: Algıllanan Risk & & & \\
$\mathrm{R}=0,789 ; \mathrm{R}^{2}=0,622 ; \mathrm{F}=212.162$ & & & \\
\hline
\end{tabular}

Tablo 9'dan görüleceği üzere, Standartlaştırılmış Regresyon Katsayısı=0,372, t=13,093, $\mathrm{p}=0,000<0,05$ değerleriyle karşılıklı iletişim değişkeninin algılanan risk üzerinde en yüksek katkıyı yaptığı dikkat çekmektedir. Yukarıda tabloda yer alan sonuçlara göre sosyal medyanın sahip olduğu özellikler algılanan riskin \%62,2'sini açıklamaktadır. Sosyal medya özelliklerinden katılım, açıklık, karşılıklı iletişim ve bağlantılı olma bağımsız değişkenlerinin tüketici tarafından algılanan riski etkilediği $(\mathrm{p}<0,05)$ tespit edilerek $\mathrm{H}_{1 \mathrm{a}}, \mathrm{H}_{1 \mathrm{~b}}, \mathrm{H}_{1 \mathrm{c}}, \mathrm{H}_{1 \mathrm{e}}$ hipotezleri kabul edilmiştir. Topluluk değişkenin algılanan riski etkilemediği $(\mathrm{p}>0,05)$ sonucuna ulaşılarak $\mathrm{H}_{1 \mathrm{~d}}$ hipotezi reddedilmiştir.

Sosyal medya özelliklerinin algılanan değere etkisini tespit etmek amacıyla çoklu regresyon analizi uygulanmıştır. Bununla birlikte yapılan analiz sonucunda DW 1,613; VIF (1,99- 2,23 arasında değişen) değerlerinin kabul edilebilir düzeyde olduğu belirlenmiştir. Yapılan regresyon analizi sonuçları Tablo 10'da gösterilmektedir.

Tablo 10

Sosyal Medya Özelliklerinin Algılanan Değere Etkisi: Regresyon Analizi Sonuçları

\begin{tabular}{lccc}
\hline Bağımsız Değişkenler & $\begin{array}{c}\text { Standartlaştırılmış Beta } \\
\text { Katsayıları }\end{array}$ & $\mathrm{p}$ \\
\hline Katılım & 0,545 & 21,151 & 0,000 \\
Açılık & 0,269 & 10,559 & 0,000 \\
Karşılıklı İletişim & 0,029 & 1,198 & 0,231 \\
Topluluk & 0,171 & 6,455 & 0,000 \\
Bağlantılı olma & 0,038 & 1,521 & 0,129 \\
Bağımlı Değişken: Algılanan Değer & & & \\
$\mathrm{R}=0,904 ; \mathrm{R}^{2}=0,816 ; \mathrm{F}=521,345$ & & & \\
\hline
\end{tabular}

Tablo 10'dan görüleceği üzere, Standartlaştırılmış Regresyon Katsayısı $=0,545 ; \mathrm{t}=21,151$; $\mathrm{p}=0,000<0,05$ değerleriyle katılım değişkeninin algılanan değere en yüksek katkıyı yaptığ 1 dikkat çekmektedir. Yukarıda tabloda yer alan sonuçlara göre sosyal medyanın sahip olduğu özellikler algılanan değerin \%81,6'sını açıklamaktadır. Sosyal medya özelliklerinden katılım, açıklık, topluluk 
bağımsız değişkenlerinin tüketici tarafından algılanan değeri etkilediği tespit edilmiştir $(\mathrm{p}<0,05)$. Dolayısıyla $\mathrm{H}_{2 \mathrm{a}}, \mathrm{H}_{2 \mathrm{~b}}, \mathrm{H}_{1 \mathrm{~d}}$ hipotezleri kabul edilmiştir. Bununla birlikte, karşıllklı iletişim ve bağlantılı olma değişkenlerinin tüketici tarafından algılanan değeri etkilemediği sonucuna ulaşılmaktadır ( $>0,05) . \mathrm{H}_{2 \mathrm{c}}$ ve $\mathrm{H}_{2 \mathrm{e}}$ hipotezi reddedilmiştir.

Sosyal medya özelliklerinin güvene etkisini tespit etmek amaciyla çoklu regresyon analizi uygulanmıştır. Bununla birlikte DW 1,692; VIF (1,99- 2,23 arasında değişen) değerlerinin kabul edilebilir düzeyde olduğu tespit edilmiştir. Analiz sonuçları Tablo 11'de gösterilmiştir.

Tablo 11

Sosyal Medya Özelliklerinin Güvene Etkisi: Regresyon Analizi Sonuçları

\begin{tabular}{lccc}
\hline Bağımsız Değişkenler & $\begin{array}{c}\text { Standartlaştırılmış Beta } \\
\text { Katsayıları }\end{array}$ & $\mathrm{t}$ \\
\hline Katılım & 0,301 & 7,098 & 0,000 \\
Açıklık & 0,037 & 0,871 & 0,384 \\
Karşılıklı İletişim & 0,177 & 4,505 & 0,000 \\
Topluluk & 0,135 & 3,095 & 0,002 \\
Bağlantılı olma & 0,224 & 5,445 & 0,000 \\
Bağımlı Değişken: Güven & & & \\
$\mathrm{R}=0,710 ; \mathrm{R}^{2}=0,499 ; \mathrm{F}=118,920 ; \mathrm{p}=0.000$ & & & \\
\hline
\end{tabular}

Tablo 11'den görüleceği üzere, Standartlaştırılmış Regresyon Katsayısı $=0,301, \mathrm{t}=7,098$, $\mathrm{p}=0,000<0,05$ değerleriyle katılım değişkeninin tüketici sosyal medyaya duyduğu güven üzerinde en yüksek katkıyı yaptığı dikkat çekmektedir. Yukarıda tabloda yer alan sonuçlara göre sosyal medyanın sahip olduğu özellikler algılanan değerin \%49,9'unu açıklamaktadır. Sosyal medya özelliklerinden katılım, karş1lıklı iletişim, topluluk ve bağlantılı olma bağımsız değişkenlerinin tüketicinin sosyal medyaya duyduğu güveni etkilediği tespit edilmiştir $(\mathrm{p}<0,05)$. Dolayısıyla $\mathrm{H}_{3 \mathrm{a}}, \mathrm{H}_{3 c}, \mathrm{H}_{3 \mathrm{~d}}$ ve $\mathrm{H}_{3 \mathrm{e}}$ hipotezleri kabul edilmiştir. Ancak açıklık değişkenin tüketicinin sosyal medyaya duyduğu güveni etkilemediği sonucuna ulaşılmıştır ( $p>0,05)$. $\mathrm{H}_{3 \mathrm{~b}}$ hipotezi reddedilmiştir.

Tüketici tarafından algılanan risk, algılanan değer ve güvenin satın alma niyetine etkisini tespit etmek amacıyla çoklu regresyon analizi uygulanmadan önce değişkenler arasında çoklu bağlantının olup olmadığını tespit etmek için bağımsız değişkenler arasındaki ikili korelasyonlar incelenmiştir. Tablo 12 incelendiğinde bağımsız değişkenler arasında 0,80'nin üzerinde bir korelasyon değeri bulunmamıştır. Bununla birlikte DW 1,709; VIF (1,97- 2,74 arasında değişen) değerlerinin kabul edilebilir düzeyde olduğu tespit edilmiştir.

Tablo 12

Değişkenler Arasındaki Korelasyon Değerleri

\begin{tabular}{lccc}
\hline $\mathrm{N}=592$ & Algılanan Risk & Algılanan Değer & Güven \\
Algılanan Risk & 1,000 & 0,735 & 0,600 \\
Algilanan Değer & & 1,000 & 0,688 \\
Güven & & 1,000 \\
\hline
\end{tabular}

Tüketici tarafından algılanan risk, algılanan değer ve güvenin satın alma niyetine etkisini tespit etmek amacıyla yapılan regresyon analizi sonuçları Tablo 13'de verilmiştir.

Tablo 13

Algılanan Risk, Algılanan Değer ve Güvenin Satın Alma Niyetine Etkisi: Regresyon Analizi Sonuçlart

\begin{tabular}{lccc}
\hline Bağımsız Değişkenler & $\begin{array}{c}\text { Standartlaştırılmış Beta } \\
\text { Katsayıları }\end{array}$ & $\mathrm{t}$ & $\mathrm{p}$ \\
Algılanan Risk & 0,298 & 7,336 & 0,000 \\
Algıllanan Değer & 0,325 & 7,271 & 0,000 \\
Güven & 0,227 & 5,984 & 0,000
\end{tabular}


Bağımlı Değişken: Satın Alma Niyeti

$\mathrm{R}=0,756 ; \mathrm{R}^{2}=0,569 ; \mathrm{F}=118,920 ; \mathrm{p}=0.000$

Tablo 13'den görüleceği üzere, Standartlaştırılmış Regresyon Katsayısı=0,325, t=7,271, $\mathrm{p}=0,000<0,05$ değerleriyle algılanan değerin satın alma niyetinde en yüksek katkıyı yaptığ dikkat çekmektedir. Yukarıda tabloda yer alan sonuçlara göre, sosyal medyadan algılanan risk, algılanan değer ve güven tüketicilerin satın alma niyetinin \%56,9'unu açıklamaktadır. Elde dilen sonuçlar, sosyal medyadan algılanan risk, algılanan değer ve güvenin tüketicilerin satın alma niyetini etkilediğini göstermektedir. Dolayısıyla $\mathrm{H}_{4}, \mathrm{H}_{5}$ ve $\mathrm{H}_{6}$ hipotezleri kabul edilmiştir $(\mathrm{p}<0,05)$.

\section{Sonuç, Tartışma ve Öneriler}

$\mathrm{Bu}$ çalışmada sosyal medyanın özelliklerinin tüketicilerin sosyal medyadan algıladığı risk, algıladığı değer ve güven üzerindeki etkisi ile tüketicilerin sosyal medyadan algıladığı risk, algıladığı değer ve güvenin satın alma niyetine etkisi araştırılmıştır.

Elde edilen veriler değerlendirildiğinde, sosyal medyanın katılım, açıklık, karşılıklı iletişim ve bağlantılı olma özellikleri tüketici tarafından algılanan riski etkilerken, topluluk özelliğinin algılanan riski etkilemediği tespit edilmiştir. Sosyal medyanın katılım, açıklık, topluluk özellikleri tüketici tarafından algılanan değer üzerinde etkili iken; karşılıklı iletişim ve bağlantılı olma özellikleri algılanan risk üzerinde etkisi olmadığı belirlenmiştir. Bununla birlikte sosyal medyanın katılım, karşılıklı iletişim, topluluk ve bağlantılı olma özelliklerinin tüketicinin sosyal medyaya duyduğu güveni etkilediği, açıklık özelliğinin ise etkisi olmadığı tespit edilmiş̧ir. Sonuçlar, sosyal medyada tüketicilerin birbirleriyle iletişim ve etkileşim içerisinde bulunmaları algılanan risk üzerinde en fazla etkiye sahip olduğunu göstermektedir. Bununla birlikte, tüketicilerin sosyal medyada istek ve tercihlerini iletebilme ve geri bildirim alabilme sosyal medyadan algılanan değer ve güven üzerinde en fazla etkiyi yaptığı belirlenmiştir.

Sosyal medyadan algılanan risk, algılanan değer ve güven tüketicilerin satın alma niyetini etkilerken, algılanan değerin satın alma niyeti üzerinde en fazla etkiye sahip olduğu bu araştırmanın en önemli bulgularından biridir. Permatasari ve Kuswadi (2018), algılanan değerin, tüketicilerin e-ticaret sitelerinde satın alma niyetinde en önemli kriter haline geldiğini öne sürmüştür. Bununla birlikte, Frost, Goode ve Hart (2010) ve Wu, Chen, Chen ve Cheng (2014) algılanan değerin, satın alma niyeti ve yeniden satın alma üzerinde oldukça etkili olduğunu ileri sürmüştür. Satın alma niyeti üzerinde algılanan riskin (Park, Lennon ve Stoel, 2005; Yanık 2015), ve güvenin (Akroush ve Al-Debei, 2015; Chaturvedi vd., 2016; El-Ansary, 2013; Ling vd., 2010; Verhagen, Meents ve Tan, 2006) etkili olduğunu göstermektedir.

İnternet üzerinde alışveriş işlemlerinde gizlilik, kalite, iade, teslimat sorunu gibi riskler nedeniyle tüketiciler satın alma konusunda isteksiz davranmaktadır. İşletmeler, bu riskleri azaltma yollarını bularak satın alımları arttırabilir böylece sadık müşteriler yaratabilir. Çevrimiçi satış yapan işletmeler, sosyal medya aracılığıyla iyi erişim sağlayan web siteleri oluşturma, sosyal medyada etkinlikler düzenleme, gruplar ve topluluklar oluşturma gibi faaliyetler ile tüketicilerle ilişkileri sürdürerek değer arttırabilir. Bununla birlikte, kullanıcılara, tüketim alışkanlıklarına ve tercihlerine göre kişiselleştirilmiş hizmet sunabilir. Böylece işletmeler kullanıcılarına keyifli bir alışveriş deneyimi sunarak memnuniyeti arttıracak ve tüketicilerin satın almalarını sağlayabilecektir.

Sosyal medya özellikleri, sosyal medyadan algılanan risk, algılanan değer, güven ve satın alma niyeti değişkenlerinin hepsini birlikte ele alan bir çalışma yapılmamış olması, elde edilen bulguların gelecekteki çalışmalara yol gösterme açısından katkı sağlayacağı düşünülmektedir.

$\mathrm{Bu}$ çalışmanın bulguları tüm çalışmalarda olduğu gibi birtakım kısıtlar altında geçerlidir. Çalışmanın görece olarak düşük sayıda bir örneklem üzerinde yapılmış olması ve örnekleme yöntemi olarak da kolayda örnekleme yönteminin tercih edilmiş olması önemli bir kısıttır. Çalışma farklı örneklemlerde tekrar edilebilir. Çalışmada algılanan risk; finansal risk, ürün riski, uygunluk ve teslim 
edilmeme riski gibi boyutlara ayrılmamıştır. İleriki çalışmalarda farklı türdeki riskler ele alınabilir. Ayrıca, tüketicilerin sosyal medya platformlarındaki satın alma davranışlarında diğer değişkenlerin de etkisi değerlendirilebilir.

\section{Kaynaklar}

Akel, G. (2015). Tüketicilerin internetten satın alma niyeti üzerine bir çalışma: Adnan Menderes Üniversitesi Örneği. (Yayınlanmamış Yüksek Lisans Tezi). Pamukkale Üniversitesi, Denizli.

Akroush, M.N. and Al-Debei, M. M. (2015). An integrated model of factors affecting consumer attitudes towards online shopping. Business Process Management Journal, 21(6), 1353-1376.

Alarçin, M. (2015). Algllanan değerin tüketici karar verme türlerine etkisi ve GSM operatörü kullanıcıları üzerine bir araştırma. (Yayınlanmamış Yüksek Lisans Tezi). Marmara Üniversitesi, İstanbul.

Aren, S., Güzel, M., Kabadayı, E. ve Alpkan, L. (2013). Factors affecting repurchase intention to shop at the same website. Social and Behavioral Sciences, 99, 536-544.

Baş, F. C. (2018). Sosyal medya davranışının oluşumu: çevrimiçi ortamlarda güven, sosyal sermaye ve saygınlık ilişkisi. Sosyoloji Araştırmaları Dergisi, 21(2), 49-85.

Beldad, A., Jong, M. and Steehouder, M. (2010). How shall I trust the faceless and the intangible? A literature review on the antecedents of online trust. Computers in Human Behavior, 26, 857869.

Chaturvedi, S., Gupta, S. and Hada, D. S. (2016). Perceived risk, trust and information seeking behavior as antecedents of online apparel buying behavior in India: an exploratory study in context of Rajasthan. International Review of Management and Marketing, 6(4), 935-943.

Chen, L. (2014). The influence of social media on consumer behavior: An empirical study on factors influencing consumer purchase intention in China under the social media context. Denmark: Aarhus University.

Chuaha, H. W., Marimuthu, M. and Ramayah, T. (2014). The effect of perceived value on the loyalty of generation Y mobile Internet subscribers: A proposed conceptual framework. Social and Behavioral Sciences, 130, 532 - 541.

Cocosila, M. and Igonor, A. (2012). Perceived value of social media: An empirical investigation. International Conference on Information Resources Management (CONF-IRM).

Çetin, O. I. ve Kumkale, İ. (2016). Sosyal medya kullanım düzeyi ve satın alma niyeti arasındaki ilişkide faydacı motivasyonun aracı etkisi. Balkan ve Yakın Doğu Sosyal Bilimler Dergisi, 2(4), $90-101$.

Demirgüneş, B. K. (2015). Relative importance of perceived value, satisfaction and perceived risk on willingness to pay more. International Review of Management and Marketing, 5(4), 211-220.

El-Ansary, O. (2013), Factors affecting Egyptian consumers' intentions for accepting online shopping. The Journal of American Academy of Business, 19(1), 191-201.

Erol, Ö. (2012). Ürün Yerleştirmeye Ürün Yerleştirmeye Yönelik Tutum ve Yerleştirilen Ürünlere Yönelik Davranışların Sosyalleşme Araçları ile Açıklanması. (Yayınlanmamış Yüksek Lisans Tezi). Hacettepe Üniversitesi, Ankara. 
Esen, F. Ö. (2012). Web sitesi kalite algısı ve imaj tutarlılı̆̆ının satın alma niyetine etkisi. (Yayınlanmamış Yüksek Lisans Tezi). Adnan Menderes Üniversitesi, Aydın.

Eskiler, E. ve Altunışık, R. (2015). Algılanan değer ve müşteri memnuniyetinin satın alma eğilimleri üzerine etkisi. III. Rekreasyon Araştırmaları Kongresi, 483-493.

Fandos, C. and Flavian, C. (2006). Intrinsic and extrinsic quality attributes, loyalty and buying intention: An analysis for a PDO product. British Food Journal, 108(8), 646-662.

Fong, N. H. and Yazdanifard, R. (2014). The impacts of social media marketing, perceived risks and domain specific innovativeness on online consumer behavior. Global Journal of Commerce \& Management Perspective, 3(2), 22-26.

Forsythe, S. M. and Shi, B. (2003). Consumer patronage and risk perceptions in Internet shopping. Journal of Business Research, 56, 867-875.

Frost, D., Goode, S. and Hart, D. (2010). Individualist and collectivist factors affecting online repurchase intentions. Internet Research, 20 (1), 6-28.

Gan, C. and Wang, W. (2017). Purchase intention in social commerce context. Internet Research, 27(4), 772-785.

Hair, J. R. Anderson, R. and Tatham, W. B. (1998). Multivariate data analysis with readings, Fifth Edition, Prentice- Hall International, Inc.

Hassan, A. M., Kunz, M. B., Pearson, A. W. and Mohamed, F. A. (2006). Conceptualization and measurement of perceived risk in online shopping. The Marketing Management Journal, 16(1), $138-147$.

https://dijilopedi.com, Türkiye İnternet kullanım ve sosyal medya istatistikleri, Erişim Tarihi: 5 Haziran, 2019.

Javadi, M. H. M., Dolatabadi, H. R., Nourbakhsh, M., Poursaeedi, A. and Asadollahi, A. R. (2012). An analysis of factors affecting on online shopping behavior of consumers. International Journal of Marketing Studies, 4(5), 81-98.

Kalburan, Ç. ve Haşıloğlu S. B. (2015). İnternet’ten alışverişte tüketiciler tarafından algılanan riskler ve risk azaltma çabaları. International Conference on Eurasian Economies, 750-754.

Khan, A. and Chavan, C.R. (2015), Factors affecting on-line shopper's behavior for electronic goods purchasing in Mumbai: An empirical study. International Journal in Management and Social Science, 3(3), 467-476.

Küçüksille, E. (2010). SPSS uygulamalı çok değişkenli istatistik teknikleri. (Ed.). Ş. Kalayc1. (ss.259269). Ankara: Asil Yayın Dağıtım.

Küpeli, T. Ş. (2014). Algılanan risk ve algllanan değer arasındaki ilişkilerin otel müşsterileri üzerinde incelenmesi. Yüksek Lisans Tezi. Hacettepe Üniversitesi, Ankara.

Ling, K. C., Chai, L. T. and Piew, T. H. (2010). The effects of shopping orientations, online trust and prior online purchase experience toward customers' online purchase intention. International Business Research, 3(3), 63-76.

Malhotra, N. K. (1999). Marketing research: An applied orientation (Third Edition). Upper Saddle River New Jersey: Prentice Hall. 
Mayfield, A. (2008). "What is social media?" http://www.icrossing.co.uk/fileadmin/uploads/eBooks/What_is_Social_Media_iCrossing_e book.pdf (Erişim Tarihi, 22 Mayıs 2019).

Maziriri, E. T. and Chuchu, T. (2017). The conception of consumer perceived risk towards online purchases of apparel and an idiosyncratic scrutiny of perceived social risk: A review of literature. International Review of Management and Marketing, 7(3), 257-265.

McKnight, D. H. and Chervany, N.L. (2002). What trust means in e-commerce customer relationships: An interdisciplinary conceptual typology. International Journal of Electronic Commerce, 6, 3560.

Özçifçi, V. (2019). Sosyal medya bağımlılı̆̆ı ve sosyal medyadan algılanan faydanın tüketici satın alma davranışına etkisi. (Ed.) B. Nakıboğlu, Pazarlama Araştırmaları I (ss.145-166). Ankara: Akademisyen Kitabevi.

Park, J., Lennon, S. and Stoel, L. (2005). On-line product presentation: Effects on mood, perceived risk, and purchase intention. Psychology \& Marketing, 22(9), 695-719.

Permatasari, A. and Kuswadi, E. (2018). The impact of social media on consumers' purchase intention: A study of ecommerce sites in Jakarta, Indonesia. Review of Integrative Business and Economics Research, 6(1), 321-335.

Petrick, J. F. (2004). The roles of quality, value, and satisfaction in predicting cruise passengers' behavioral intentions. Journal of Travel Research, 42, 397-407.

Tabachnick, B. G. and L. S. Fidell (2001). Using multivarite statistics (Fourht Edition), Allyn \& Bacon, a Pearson Education Company.

Tektaş, Ö. Ö. ve Kavak, B. (2010). Endüstriyel ürünlerin satın alınması sürecinde tedarikçi ile olan ilişki kalitesinin algılanan değer üzerindeki etkisi: Beş yıldızlı otellerde bir araştırma. Anatolia: Turizm Araştırmaları Dergisi, 21(1), 51-63.

Türkmendağ, T. ve Köroğlu, A. (2018). Algılanan değerin marka kişiliği üzerine etkisi. Uluslararası Yönetim İktisat ve İsletme Dergisi, 14(4), 1121-1146.

Uzunoğlu, E. (2007). Müssteri odaklı pazarlama anlayışına göre değer yaratma: bir model olarak değer iletim sistemi. Eskişehir Osmangazi Üniversitesi İ̈BF Dergisi, 2(1), 11-29.

Vatandaş, S. (2017). Sosyal medyanın anlam ve öneminin cinsiyetler bağlamında incelenmesi. Uluslararası Yönetim ve Sosyal Araştırmalar Dergisi, 4(8), 12-24.

Verhagen, T., Meents, S. and Tan, Y.H. (2006). Perceived risk and trust associated with purchasing at electronic marketplace. European Journal of Information Systems, 15(6), 542-555.

Vural, Z. B. A. ve Bat, M. (2010). Yeni bir iletişim ortamı olarak sosyal medya: Ege Üniversitesi İletişim Fakültesi’ne yönelik bir araştırma. Journal of Yaşar University, 2085, 3348-3382.

Yanık, A. (2014). Yeni medya kullanımındaki akış deneyiminin risk algısı ve online turistik satın alma niyetine etkisi. Yayınlanmamış Yüksek Lisans Tezi, Adnan Menderes Üniversitesi, Aydın.

Wang, J-C. and Chang, C. H. (2013). How online social ties and product- related risks influence purchase intentions: A Facebook experiment. Electronic Commerce Research and Application, 12, 337- 346. 
Wu, L-Y., Chen, K-Y, Chen, P-Y and Cheng, S-L. (2014). Perceived value, transaction cost, and repurchase-intention in online shopping: A relational exchange perspective. Journal of Business Research, 67, 2768-2776.

Zeithaml, V. A. (1988). Consumer perception of price, quality, and value-A means-end model and synthesis of evidence. Journal of Marketing, 52, 2-22. 


\section{Extended Abstract}

\section{Introduction}

Increased use and access to the Internet has changed the way of getting information, products and services. Accordingly, the creation of online sites to carry out commercial activities over the Internet has been one of the major transformations in the market. This process directed consumers to review and purchase products online. During this process, businesses started to change their approach toward their target audience by using social media campaigns, e-mails, forums and e-commerce websites. Social media platforms offer an environment in which individuals can exchange information about the most appropriate products and services, while providing new communication and marketing channels for businesses. Thus, social media has become one of the most popular communication channels for marketing and promoting products and services.

The key objective of this paper can be expressed as examining the factors affecting the way how consumers acquire information and make purchases through social media, and the effect of social media on consumers' intention to purchase. The effect of perceived risk, perceived value, and trust factors on purchasing intention, which are influential over consumers' online purchasing behavior was also examined.

While social media is an effective communication process for establishing relationships, building trust, and reaching and connecting with other people, it is primarily related to the use of information technologies and has some essential characteristics. These features can be listed as participation, openness, mutual communication, community, and being connected (Mayfield, 2008).

The perceived risk of online shopping is the customers' subjectively determined expectation of loss in terms of the idea of buying online. When shopping online, consumers express more than one concern for each type of risk (Kalburan and Haşıloğlu, 2015). The lower the risk a consumer perceives, the higher the tendency toward online shopping becomes (Javadi et al., 2012). However, perceived risk may have different effects depending on consumers' online shopping behavior, online shopping habits and experiences (Forsythe ve Shi, 2003).

Today, when the consumers make a purchasing decision, they act according to how they perceived the value the product is meant to provide. The perceived value due to its complexity and multilaterality serves as a lens to examine the social media practices (Cocosila and Igonor, 2012).

Trust is one of the important variables that affect consumers' online shopping behavior. Today, as consumers are extremely connected with social media, their perceptions and trust in products are highly influenced by comments, opinions and communities in the social media environment (Ling et al., 2010; Chaturvedi et al., 2016; Aren et al., 2013).

The intention to buy implies the predictable behavior of the consumers, ie it can be used to predict which products or brands consumers will buy next time they shop (Fandos and Flavian, 2006).

\section{Method}

The target group of the study is people aged 18 and over who use social media. The convenience sampling method was chosen because of the large population and lack of sampling frame. Data from 620 participants were collected and 592 of them were evaluated in the questionnaire analysis.

In this study, questionnaire method was used as data collection method. The questionnaire was administered to the participants both online and in print. The survey consists of two parts. In the first part, demographic characteristics of the participants are asked. In the second part, expressions about the five basic characteristics of social media from Myfield, 2008; and Chen, (2014), 6 statements about perceived risk from social media from Hassan, et al., (2006); 3 expressions related to perceived 
value from Zeithaml, (1988); Petrick, (2004); 4 statements on trust from Chen, (2014); 4 expressions of intention to purchase from Wang and Chang (2013); and McKnight and Chervany (2002) was inquired. Factor Analysis and Multiple Standard Regression were used to analyze the collected data.

\section{Results, Conclusion and Suggestions}

It has been revealed that the characteristics of social media differ according to perceived risk, perceived value and trust factors of consumers from social media. While the highest impact on perceived risk is the mutual communication variable of social media, participation variable makes the most impact on perceived value and trust. It was determined that perceived risk has no effect on community, inter-communication and relatedness have no impact on perceived value, and openness variable has no effect on trust. In addition, it was also found that consumers' perceived risk, perceived value and trust from social media affect the consumers' purchasing intention. Lastly, it was found that the variable that has the greatest effect on purchase intention was perceived value.

The results show that the communication and interaction of consumers on social media has the greatest effect on perceived risk. In addition, it was determined that the ability of consumers to convey their wishes and preferences on social media and receive feedback had the greatest effect on perceived value and trust from social media. Consumers are reluctant to purchase due to risks such as confidentiality, quality, return and delivery problems in online shopping transactions. Businesses can find ways to mitigate these risks and increase purchases so that they can create loyal customers.

While the perceived risk, perceived value and trust from social media affects consumers' buying intention, one of the most important findings of this research is that perceived value has the greatest impact on the intention to purchase. Online businesses will be able to increase value by maintaining relationships with consumers through activities such as creating websites that provide good access through social media, organizing events on social media, creating groups and communities.

As in all studies, the findings of this study are valid under a number of constraints. An important limitation is that the study was carried out on a relatively low number of samples and the convenience sampling method was preferred. The study can be repeated in different samples. In addition, the effect of other variables on the purchasing behavior of consumers on social media platforms can be evaluated. 